\title{
Analysis of Consumption on the Goods and Services Market in the Cybernetic Model of Selected Country
}

\author{
Pavel Rousek ${ }^{1, *}$ \\ ${ }^{1}$ Institute of Technology and Business in České Budějovice, School of Expertness and Valuation, \\ Okružní 517/10, 37001 České Budějovice, Czechia
}

\begin{abstract}
The paper analyses the consumption on the goods and services market in the cybernetic model of Czechia. The theoretical basis is given by the consumption function in the short-term, the macroeconomic multiplier of the two-sector economy and the cybernetic model with the goods and services market. All the above-mentioned theory is applied to the real conditions of the selected country, which is the Czech Republic. Key words: cybernetic model, goods and services market, consumption, macroeconomic multiplier
\end{abstract}

\section{Introduction}

A real economy is a complex system that can be simplified into an economic model with inputs, outputs, and links inside. Exogenous inputs are most often considered as autonomous components of consumption, investment, government purchases, exports and imports. The key output is then the amount of product.

One of the most important input and output parts is consumption. There is the input autonomous consumption and the output total consumption as part of the gross domestic product. This article analyses autonomous and total consumption in a two-sector economy.

\section{Data and Methods}

\subsection{Consumption in the Short-Term}

The theory of consumption function is very well explored in the professional literature of the $20^{\text {th }}$ and $21^{\text {st }}$ centuries [1-3].

Consumption function in the short-term is based on Keynesian theory. It is a relation between consumption and macroeconomic product. Mathematically expressed, these two variables are dependent and independent variable. The equation of the function is as follows in the formula (1).

\footnotetext{
* Corresponding author: rousek@mail.vstecb.cz
} 


$$
\mathrm{C}=\mathrm{C}_{0}+\mathrm{c} \times \mathrm{Y}
$$

Where:

$\mathrm{C}$ is the total consumption,

$\mathrm{C}_{0} \quad$ autonomous consumption,

$\mathrm{c} \times \mathrm{Y}$ induced consumption,

c marginal propensity to consume,

Y product.

\subsection{Macroeconomic Multiplier of the Two-Sector Economy}

The so-called Keynesian multiplication process uses the property of consumption function and especially of the post-induced consumption through the marginal propensity to consume. "The Keynesian multiplier process is the economist's paradigmatic positive feedback loop, in which an initial departure from full-employment equilibrium cumulates instead of being corrected" [4].

The principle of multiplication is infinite and weakening repetition of the original impulse, which is the change in autonomous expenditures. Mathematical evaluation of the strength of the effect is given by the formula (2).

$$
\Delta \mathrm{Y}=\Delta\left(\mathrm{C}_{0}+\mathrm{I}_{0}+\mathrm{G}_{0}+\mathrm{NX}\right) \times \frac{1}{1-\mathrm{c}}
$$

Where:

$\mathrm{Y}$ is the product (GDP),

$\mathrm{C}_{0} \quad$ autonomous consumption,

$\mathrm{I}_{0} \quad$ autonomous investments,

$\mathrm{G}_{0} \quad$ autonomous government purchases,

NX net export,

c marginal propensity to consume.

\subsection{Cybernetic Model with the Goods and Services Market}

"Cybernetics allows expression of the dependence of output change $\Delta \mathrm{Y}$ on exogenous input changes $\Delta(\mathrm{C} 0+\mathrm{I} 0+\mathrm{G} 0+\mathrm{NX})$ " [5]. Cybernetic model with the goods and services market has following parameters:

- Inputs

- Autonomous consumption $\mathrm{C}_{0}$

○ Other autonomous expenditures $\mathrm{I}_{0}+\mathrm{G}_{0}+\mathrm{NX}$

- Internal feedback

- Marginal propensity to consume c

- Output

○ Product $Y$

A constant price level is assumed, which can be achieved by calculations with input parameters at constant prices. The graphical interpretation of the above is shown in Fig. 1. 


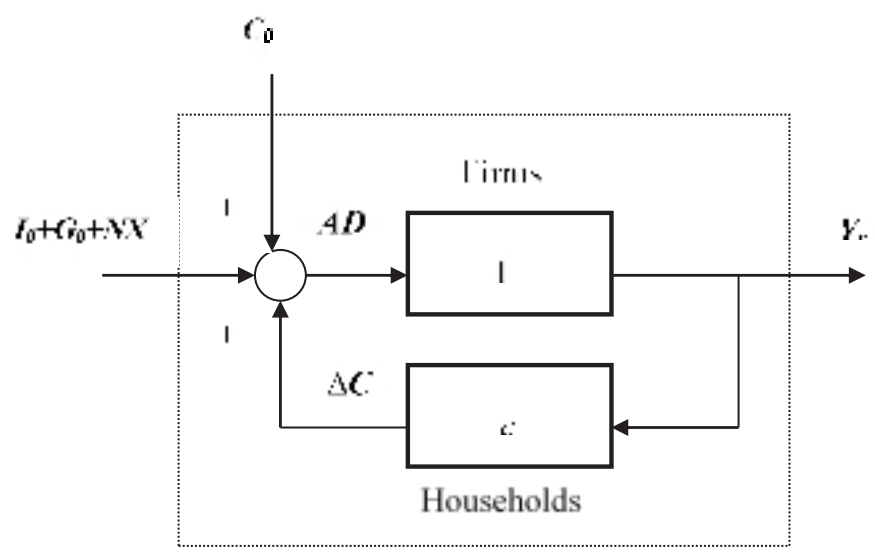

Fig. 1. Cybernetic Model of a Static Economy with the Goods and Services Market Source: [6].

\section{Results and Discussion}

\subsection{Consumption in Selected Country}

Under the conditions of the Czech Republic, objective time series can begin in 1993 when Czechia and Slovakia became independent. In this case, the relevant data can be traced back to 1996 as shown in Table 1.

Table 1. Consumption and product data of the Czech Republic (in CZK million, constant prices) [7].

\begin{tabular}{|l|r|r|}
\hline & Product & Consumption \\
\hline 2017 & 4612481 & 3052490 \\
\hline 2016 & 4418198 & 2955606 \\
\hline 2015 & 4306516 & 2865773 \\
\hline 2014 & 4089400 & 2777475 \\
\hline 2013 & 3981303 & 2734118 \\
\hline 2012 & 4000653 & 2704547 \\
\hline 2011 & 4032910 & 2743834 \\
\hline 2010 & 3962464 & 2765219 \\
\hline 2009 & 3874383 & 2741341 \\
\hline 2008 & 4069840 & 2731172 \\
\hline 2007 & 3963527 & 2667991 \\
\hline 2006 & 3753246 & 2587425 \\
\hline 2005 & 3512515 & 2516852 \\
\hline 2004 & 3297100 & 2453097 \\
\hline 2003 & 3142892 & 2408273 \\
\hline 2002 & 3033592 & 2290145 \\
\hline 2001 & 2984277 & 2193217 \\
\hline 2000 & 2899925 & 2164111 \\
\hline 1999 & 2781256 & 2113471 \\
\hline 1998 & 2741968 & 2050586 \\
\hline 1997 & 2751011 & 2074671 \\
\hline 1996 & 2767468 & 2014077 \\
\hline
\end{tabular}

Source: [7]. 
By fitting the regression line with these points, an accurate consumption function with $\mathrm{R}^{2}$ $=0.9781$ is obtained. The parameters of this consumption function are $\mathrm{c}=0.5137$ and $\mathrm{C}_{0}=$ 683545 (Fig. 2). The complete consumption function is given in equation (3).

$$
\mathrm{C}=683545+0.5137 \times \mathrm{Y}
$$

Where:

$\mathrm{C}$ is the total consumption,

$\mathrm{C}_{0} \quad$ autonomous consumption,

$\mathrm{c} \times \mathrm{Y}$ induced consumption,

c marginal propensity to consume,

Y product.

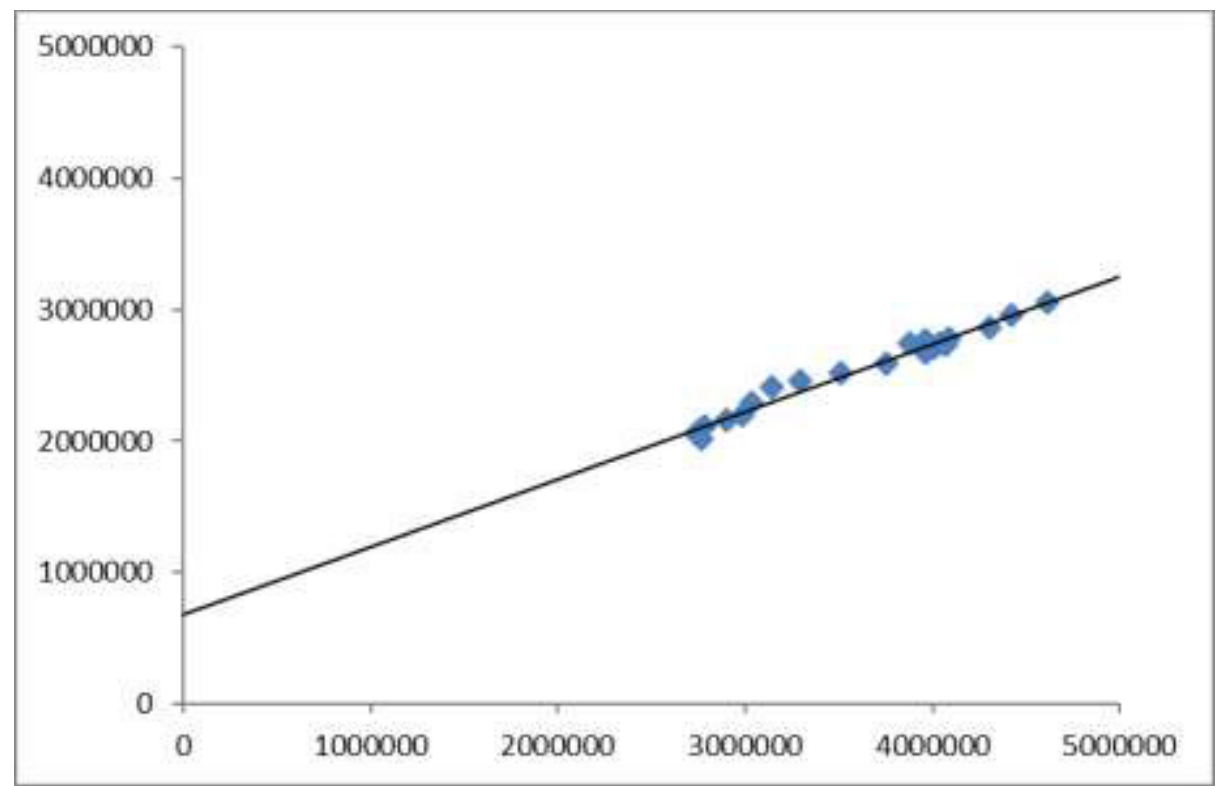

Fig. 2. Consumption Function in the Czech Republic.

Source: Author.

\subsection{Macroeconomic Multipliers in Selected Country}

The Keynesian multiplier is naturally based on the values of the consumption function, autonomous consumption and the marginal propensity to consume. For the Czech Republic, the calculation method (4) and the value of the multiplier (5) apply.

$$
\begin{aligned}
& \Delta \mathrm{Y}=\Delta\left(683545+\mathrm{I}_{0}+\mathrm{G}_{0}+\mathrm{NX}\right) \times \frac{1}{1-0.5137} \\
& \Delta \mathrm{Y}=\Delta\left(683545+\mathrm{I}_{0}+\mathrm{G}_{0}+\mathrm{NX}\right) \times 2,0563
\end{aligned}
$$

Where:

$\mathrm{Y}$ is the product (GDP),

$\mathrm{C}_{0} \quad$ autonomous consumption,

$\mathrm{I}_{0} \quad$ autonomous investments,

$\mathrm{G}_{0} \quad$ autonomous government purchases, 
NX net export,

c marginal propensity to consume.

\subsection{Cybernetic Model of Selected Country}

The cybernetic model of the Czech Republic is supplemented by specific values of autonomous consumption $\mathrm{C}_{0}=683545$, and marginal propensity to consume $\mathrm{c}=0.5137$. This means that the change in any autonomous expenditures (autonomous investments, autonomous government spending, net exports) will be 2.0563 times in the economy.

Fig. 3 shows an actual cybernetic model of the Czech Republic with the goods and services market.

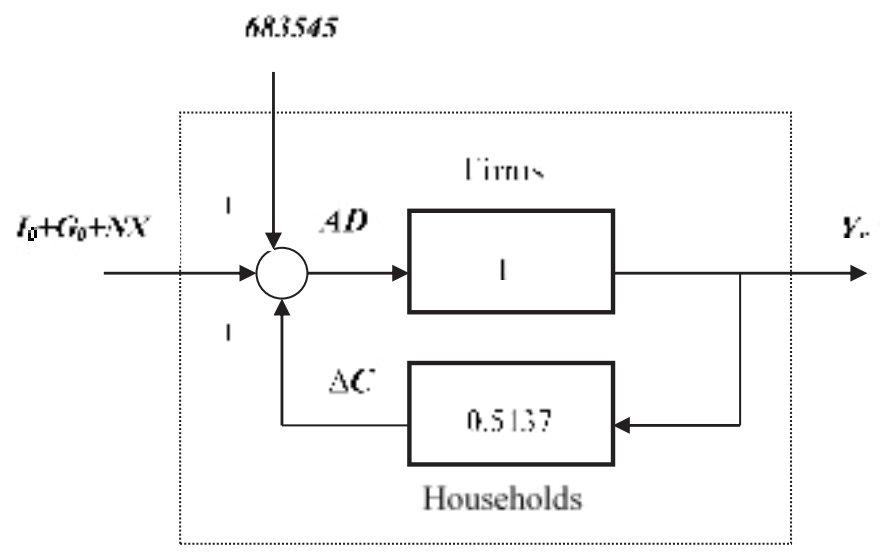

Fig. 3. Cybernetic Model of the Czech Republic with the Goods and Services Market Source: Author.

\subsection{Complex Dataset of Selected Country}

Czechia can be described from the point of view of consumption, Keynesian multiplier and cyber model by the parameters in Table 2 .

Individual quantities were determined as follows:

- $\mathrm{Y}$ - real data,

- $\mathrm{C}$ - real data,

- $\mathrm{C}_{0}+\mathrm{I}_{0}+\mathrm{G}_{0}+\mathrm{NX}$ as the total input of cybernetic model,

- $\mathrm{C}_{0}$ as one parameter of the consumption function,

- $\mathrm{I}_{0}+\mathrm{G}_{0}+\mathrm{NX}$ as the difference between cybernetic model and consumption function data. 
Table 2. Consumption and product data of the Czech Republic (in CZK million, constant prices).

\begin{tabular}{|l|c|r|r|r|r|}
\hline & $\begin{array}{c}\text { Product } \\
\mathbf{Y}\end{array}$ & $\begin{array}{c}\text { Total } \\
\text { Consumption } \\
\mathbf{C}\end{array}$ & $\begin{array}{c}\text { Total } \\
\text { Autonomous } \\
\text { Expenditures } \\
\mathbf{C}_{\mathbf{0}}+\mathbf{I}_{\mathbf{0}}+\mathbf{G}_{\mathbf{0}}+\mathbf{N X}\end{array}$ & $\begin{array}{c}\text { Autonomous } \\
\text { Consumption } \\
\mathbf{C}_{\mathbf{0}}\end{array}$ & $\begin{array}{c}\text { Non- } \\
\text { consumption } \\
\text { Autonomous } \\
\text { Expenditures } \\
\mathbf{I}_{\mathbf{0}}+\mathbf{G}_{\mathbf{0}}+\mathbf{N X}\end{array}$ \\
\hline 2017 & 4612481 & 3052490 & 2243050 & 683545 & 1559505 \\
\hline 2016 & 4418198 & 2955606 & 2148570 & 683545 & 1465025 \\
\hline 2015 & 4306516 & 2865773 & 2094259 & 683545 & 1410714 \\
\hline 2014 & 4089400 & 2777475 & 1988675 & 683545 & 1305130 \\
\hline 2013 & 3981303 & 2734118 & 1936108 & 683545 & 1252563 \\
\hline 2012 & 4000653 & 2704547 & 1945518 & 683545 & 1261973 \\
\hline 2011 & 4032910 & 2743834 & 1961204 & 683545 & 1277659 \\
\hline 2010 & 3962464 & 2765219 & 1926946 & 683545 & 1243401 \\
\hline 2009 & 3874383 & 2741341 & 1884112 & 683545 & 1200567 \\
\hline 2008 & 4069840 & 2731172 & 1979163 & 683545 & 1295618 \\
\hline 2007 & 3963527 & 2667991 & 1927463 & 683545 & 1243918 \\
\hline 2006 & 3753246 & 2587425 & 1825204 & 683545 & 1141659 \\
\hline 2005 & 3512515 & 2516852 & 1708136 & 683545 & 1024591 \\
\hline 2004 & 3297100 & 2453097 & 1603380 & 683545 & 919835 \\
\hline 2003 & 3142892 & 2408273 & 1528388 & 683545 & 844843 \\
\hline 2002 & 3033592 & 2290145 & 1475236 & 683545 & 791691 \\
\hline 2001 & 2984277 & 2193217 & 1451254 & 683545 & 767709 \\
\hline 2000 & 2899925 & 2164111 & 1410234 & 683545 & 726689 \\
\hline 1999 & 2781256 & 2113471 & 1352525 & 683545 & 668980 \\
\hline 1998 & 2741968 & 2050586 & 1333419 & 683545 & 649874 \\
\hline 1997 & 2751011 & 2074671 & 1337817 & 683545 & 654272 \\
\hline 1996 & 2767468 & 2014077 & 1345820 & 683545 & 662275 \\
\hline
\end{tabular}

Source: Author.

\section{Conclusion}

Consumption in the short-term, macroeconomic multiplier of the two-sector economy, and cybernetic model with the goods and services market have been used to define conclusions of this paper.

GDP increased by $67 \%$, consumption increased by $52 \%$, total autonomous expenditures increased by $67 \%$, autonomous consumption did not increase or decrease, and nonconsumption autonomous expenditures increased by $135 \%$. This has happened over the past two decades.

\section{References}

1. J. M. Keynes, The General Theory of Employment Interest and Money. London: Palgrave Macmillan, (1936)

2. J. M. Keynes, The 'Ex ante' theory of the rate of interest. Economic Journal, 47(188), 663-669, (1937)

3. M. Friedman, A Theory of the Consumption Function. Princeton: Princeton University Press, (1957)

4. P. Howitt, The microfoundations of the Kenyesian multiplier process. Journal of Economic Interaction and Coordination, 1(1), 33-44, (2006)

5. P. Rousek, In printing, (2018) 
6. M. Máče, P. Rousek. Makroekonomie pro technické školy. Prague: Grada, (2013)

7. Czech National Bank. Available at:

https://www.cnb.cz/cnb/STAT.ARADY_PKG.PARAMETRY_SESTAVY?p_sestuid= 28788\&p_strid=ACCAAA\&p_lang $=$ CS (2018) 